никнення і розвиток творчих здібностей / Б. П. Нікітін // Радянська школа. - 1989. - № 7-8. - С. 43-52. 8. Педагогический словарь. М. : Педагогика. - Т. 2. - 516 с. 9. Полякова Г. Підвищення творчої активності підлітків / Г. Полякова // Психолог. - 2005. - № 7. С. 12-14. 10. Рубинштейн С. Л. Проблемы общей психологии / С. Л. Рубинштейн. - М. : Педагогика, $1976 . \quad$ - 264 с. 11. Сисоєва С. О. Основи педагогічної творчості вчителя : [навч. посібн.]. - К. : ІСДОУ. - 1994. - 112 с. 12. Теплов Б. М. Избранные труды: в 2-х т. / Б. М. Теплов. - М. : Педагогика, 1985. - Т. 1. 328 с. 13. Тушева В. В. Формувати творчу активність учнів / В. В. Тушева // Рідна школа. - 1998. - № 4. - С.67-69. 14. Щуркова Н. В. Педагогічна технологія як навчальна дисциплина / Н. В. Щуркова // Педагогіка. - 1993.- № 2.- С. 66-70.

\title{
МОТИВАЦІЯ ДО НАВЧАННЯ ЯК ПЕДАГОГІЧНА УМОВА ФОРМУВАННЯ КРОС-КУЛЬТУРНОЇ КОМПЕТЕНТНОСТІ МАЙБУТНІХ ЕКОНОМICТIB-АГРАРЇ̈В
}

У статті розкрито значення мотивації до навчання як педагогічної умови формування крос-культурної компетентності майбутніх економістів-аграріїв.

Ключові слова: мотивація, зовнішня мотивачія, внутрішня мотивачія.

В статье раскрыто значение мотивачии к обучению для формирования кросс-культурной компетентности будущих экономистов-аграриев.

Ключевые слова: мотивачия, внешняя мотивация, внутренняя мотивацุия.

It is shown the importance motivation for cross-cultural competence formation in a process of agrarian students education at economic faculties.

Key words: motivation, internal motivation, external motivation.

Нині в сучасній вищій школі (як і раніше) досить гостро постає завдання підвищення ефективності навчання й оптимізації навчально-пізнавальної діяльності студентів. Попри недостатні здібності висока навчальна мотивація може відігравати роль компенсуючого чинника, тому в педагогіці й психології приділяється особлива увага проблемі іiі формування.

Ефективна організація педагогічного процесу неможлива 
без урахування спонукальних причин, які визначають діяльність студента, тобто, аналіз та модернізація методики навчального процесу потребує дослідження проблеми мотивації як педагогічної умови формування кросс-культурної компетентності майбутніх економістів-аграріїв.

Питання мотивації людської діяльності порушувалося у працях вітчизняних й зарубіжних психологів, починаючи 3 перших десятиріч XX ст. до сьогодення (К. Мадлен, А. Маслоу, Г. Мюррей, Г. Олпорт, Х. Хекхаузен, Р. Вайсман, П. Якобсон, Л. Занков, С. Занюк, Є. Ільїн, Д. Леонтьєв та ін.). Окремі дослідження в педагогічно-методичній науці присвячені інтринсивній мотивації як рушійній силі навчального процесу учнів (І. Вартанова, С. Занюк, І. Звягінцева, М. Лук'янова, А. Маркова, С. Пасічник, Н. Хлопкова), студентів (Є. Ільїн, О. Куцевол, П. Лузін, О. Малихін, О. Семиног, О. Яцишин). Проте проблеми значення мотивації для формування кросс-культурної компетентності майбутніх економістів-аграріїв все ще залишаються невизначеними.

Meта статmi - розглянути роль мотивації в процесі формування кросс-культурної компетентності майбутніх економістів-аграріїв.

У контексті формування мотивів у процесі навчання студентів ВНЗ неодмінно виникає питання про те, які саме мотиви слід формувати. Це не просто питання пошуку та відбору того чи іншого окремо взятого мотиву 3 метою його формування, а визначення оптимальної структури мотиваційної сфери студента [8].

А. Маркова підкреслює, що «навчальна мотивація складається 3 низки спонукань (потреби і смисл навчання, його мотиви, цілі, емоції, інтереси), які постійно змінюються i вступають у нові зв'язки один 3 одним. Тому становлення мотивації - не просте зростання позитивного або послаблення негативного ставлення до навчання, а ускладнення структури мотиваційної сфери, спонукань, які входять до неї, поява нових, більш зрілих, інколи суперечливих відношень між ними» $[10$, с. 14]. Аналіз мотивації навчальної діяльності вимагає не лише визначення домінуючого мотиву, але й врахування всієї структури мотиваційної сфери людини. Розглядаючи цю сферу в контексті навчальної діяльності, А. Маркова підкреслює ієрархічність іiї будови.

Слід зазначити, що серед дослідників існують розбіжності 
в поглядах щодо пріоритетності тих чи тих видів мотивів для успішності навчальної діяльності. Найбільш адекватними навчальній діяльності окремі дослідники вважають пізнавальні мотиви (широкі пізнавальні, навчально-пізнавальні, мотиви самоосвіти) [11]. А. Маркова виокремлює якісно новий тип мотивів, специфічних для навчальної діяльності, навчально-пізнавальних, тобто спрямованість на оволодіння новими способами дій. Саме орієнтація на засвоєння способів навчально-пізнавальної діяльності забезпечує, на іiі думку, становлення суб'єкта навчальної діяльності. Однак це не означає, що пізнавальні мотиви завжди є провідними в структурі мотивації навчання.

Психологічні дослідження динаміки навчальної мотивації свідчать про значні зміни їх особистісної значущості i дієвості в процесі онтогенезу. Так, наприклад, у юнацькому віці провідну роль у навчальній діяльності відіграють мотиви самоствердження і саморозвитку, самовдосконалення. Попри безумовну цінність власне пізнавальних мотивів у навчанні не можна відмовитися від зовнішньої соціальної мотивації. Ми цілком погоджуємося 3 С. Рубінштейном у тому, що «безпосередній і опосередкований інтерес до навчання виявляються такою мірою взаємопов'язаними, що очевидною стає неможливість суто зовнішнім чином їх протиставляти» [14].

У дослідженні Н. Бондаренко подано перелік мотивів навчальної діяльності: широкі соціальні мотиви; пізнавальні мотиви, зумовлені самою навчальною діяльністю; комунікативні мотиви; мотиви участі в навчальному процесі; мотиви соціальної ідентифікації (з батьками, однолітками, педагогами); мотиви особистісного розвитку (професійного самовизначення, матеріального благополуччя); мотиви успіху (самоствердження, самовираження); мотиви уникнення неприємностей [1].

На думку В. Тимошенко, провідними у структурі навчальної мотивації $є$ комунікативні, пізнавальні та соціальні мотиви, найдієвішим серед яких є мотив досягнення - прагнення до успіху в професійній діяльності [1].

О. Леонтьєв підкреслює, що педагог має право самостійно вирішувати, на який вид мотивації учнів (студентів) слід покладатися в першу чергу - на комунікативну, пізнавальну, естетичну чи ігрову [9].

Відповідно до сучасних психологічних уявлень, категорія мотивації - це система мотивів, яка визначає конкретні фор- 
ми діяльності або поведінки людини. Класичний закон Йеркса-Додсона, сформульований кілька десятиліть тому, дозволив виявити залежність активності людини, іiі ефективної діяльності від сили мотивації. За цим законом істиним є висновок: чим вища сила мотивації, тим вища результативність діяльності [2].

Проте мотив може характеризуватися не лише кількісно (слабкий або сильний), але і якісно. У науковій літературі розрізняють різні види мотивів, які можна звести до двох груп:

- екстринсивні (зовнішні);

- інтринсивні (внутрішні, процесуальні).

Якщо для особистості (студента) має значення діяльність як така (наприклад, задовольняється пізнавальна потреба в процесі навчання), то говорять про внутрішню мотивацію. Якщо значення мають інші потреби (наприклад, потреба соціального престижу, одержання похвали, уникнення покарання тощо), то говорять про зовнішні мотиви. До зовнішних мотивів відносять також стимули, об'єктивні умови середовища, у якому перебуває людина.

Характеризуючи ці дві групи мотивів, дослідники (С. Занюк, Л. Копець, А. Маркова, П. Якобсон та ін.) зауважують, що саме внутрішні мотиви безпосередньо пов'язані 3 процесом навчальної діяльності.

За визначенням С. Занюка, «внутрішньою (процесуальною) мотивацією називають зумовленість поведінки чинниками, безпосередньо не пов'язаними 3 впливом середовища й фізіологічними потребами організму» [3, с. 98-99]. Дослідник зазначає, що процесуально мотивована поведінка здійснюється заради себе самої, вона супроводжується почуттям радості, задоволенням від власної справи [3, с. 99]. При сформованості такої позитивної мотивації, як зазначає П. Якобсон, студентом рухає «потреба в знаннях, інтерес, прагнення пізнавати нове. Людина, що навчається, отримує задоволення від приросту своїх знань під час засвоєння нового матеріалу» [5, с. 267]. Такий мотив ще називають функціональним (Л. Копець), коли емоційне задоволення приносить сам процес діяльності [7].

У наукових працях психолого-педагогічного характеру до процесуальних, зокрема, відносять пізнавальні мотиви, мотивацію досягнень, потребу в самоактуалізації, мотив творчого досягнення. Вони відповідають за якість професійного зрос- 
тання, тому зупинимося на них детальніше.

Пізнавальні мотиви, за А. Марковою, поділяються на три групи: 1) широкі пізнавальні мотиви, які полягають в орієнтації на оволодіння новими знаннями; 2) навчальнопізнавальні мотиви, спрямовані на засвоєння способів здобуття знань: інтерес до прийомів їх самостійного набуття, до методів наукового пізнання, до способів саморегуляції навчальної діяльності, раціональної організації власної навчальної праці; 3) мотиви самоосвіти, що виражаються в спрямованості на самостійне вдосконалення способів здобуття знань [10].

Самоактуалізація, або потреба особистісного самовдосконалення, в ієрархічній піраміді потреб А. Маслоу займає один iз найвищих щаблів. Піраміда тлумачиться науковцем як прагнення людини до самореалізації, до актуалізації власних потенцій [12]. Діяльність індивіда спрямована на реалізацію себе в обраній професії, бажанні, за словами А. Маслоу, «бути тим, ким він може бути» [12, с. 91]. Особистість, яка досягає цього рівня, повністю реалізує в різноманітних видах діяльності свої здібності, уміння, навички, талант. Суголосну думку висловлює американський психолог Карл Роджерс, ідентифікуючи мотив з «тенденцією до актуалізації». Науковець уважає, що прагнення людини до розвитку власних здібностей $є$ природнім процесом збереження та розвитку своєї особистості [7]. Окрему групу становить мотив творчого досягнення. Р. Вайсман трактує його як «прагнення до розв'язання певного наукового чи технічного завдання й до успіху в науковій діяльності» [3, с. 266].

Однак поділ мотивів на внутрішні та зовнішні є недостатнім, хоч і дуже важливим. Адже саме зовнішні мотиви можуть бути позитивними (мотиви успіху, досягнення) і негативними (мотиви уникнення, захисту). Дослідження показують, що для сильних студентів, як правило, характерна внутрішня мотивація: вони орієнтовані на засвоєння міцних професійних знань, навичок і практичних умінь. Навчальні мотиви слабких студентів переважно зовнішні, ситуативного характеру: уникнути осуду і покарання за погане навчання, не втратити через неуспішність стипендію тощо.

За Г. Нікітіною, мотивація умовно класифікується за трьома типами [13].

Перший, домінантний тип, пов'язаний з психологічними особливостями студента та ставленням до навчального про- 
цесу, тобто, як притаманний йому внутрішній тип мотивації. Цей тип визначає інтерес студента до конкретного предмета.

Другий тип - ситуативна мотивація, цей тип можна вважати зовнішнім щодо навчального процесу.

Третій тип - це конформістська або сугестивна мотивація. Вона пов'язана 3 розбіжностями між ціннісними орієнтаціями та реальною поведінкою особистості.

Наприклад, коли виникає ситуація перед студентом, який не має потягу до занять конкретним предметом, однак є потреба засвоїти знання з цього предмета, необхідні йому для успішної діяльності в межах обраної професії, - це є приклад конформістської мотивації. Стимулами, які спонукають таку мотивацію, $\epsilon$, наприклад, прагнення до отримання підвищеної стипендії, бажання продовжувати навчання на держбюджетному місці, бажання вступити до магістратури після одержання ступеня бакалавра.

Неважко помітити, що третій тип мотивації має примусовий характер, а це пов'язано з психологічним дискомфортом. Відповідні мотиви можуть бути малоефективними для певної категорії студентів, незважаючи на те, що застосування традиційного підходу до організації й побудови навчального процесу сприяє формуванню стимулів такого зразка.

Для високої ефективності будь-якої діяльності найбільш сприятливим $є$ таке співвідношення трьох видів мотивації: $\mathrm{BM}>3 П \mathrm{C}>3 \mathrm{HП}$; найгіршим - ЗНМ < ЗПМ < ВМ, де ВM внутрішня мотивація, ЗПМ - зовнішня позитивна мотивація, ЗНП - зовнішня негативна мотивація [4].

Розрізняють, крім мотивації діяльності, мотивацію поведінки. Це внутрішні спонуки особистості до тих чи тих вчинків, соціальних впливів і взаємодій. Необхідно сказати про два важливих типи мотивації поведінки - мотивацію успіху і мотивацію побоювання невдачі. Мотивація на успіх $\epsilon$ позитивною, людина, починаючи справу, передбачає досягнення чогось конструктивного, необхідного, в основу іiі активності покладено надію на успіх і потребу в його досягненні. Мотивація на невдачу - негативна, активність людини спрямована на уникнення зриву, осуду, покарання. Ще не розпочавши справу, людина вже боїться можливої невдачі, зовсім не сподіваючись на досягнення успіху.

Мотивація на усnіx. Такі особи, як правило, активні, ініціативні. Якщо зустрічаються перешкоди, вони шукають способи їх подолання. Продуктивність діяльності, активність 
меншою мірою залежать від зовнішнього контролю. Вони відрізняються наполегливістю в досягненні мети, схильні планувати своє майбутнє на далеку перспективу.

Мотивація на невдачу. Такі особи менш ініціативні. При виконанні відповідальних завдань шукають причини відмови від них. Обирають завдання або дуже легкі, або нереальні. Відрізняються меншою наполегливістю у досягненні мети.

Внутрішніми чинниками формування тієї чи іншої мотивації $\epsilon$ потреби. Потреба - це необхідність в об'єктивних умовах, предметах, об'єктах, без яких неможливі розвиток та існування живих організмів, їх життедіяльність. Потреба розглядається як особливий психічний стан індивіда, що відчуває або усвідомлює свою «напругу», «незадоволення», «дискомфорт», як відображення в психіці людини невідповідності між внутрішніми і зовнішніми умовами діяльності. Незадоволення життєво важливих потреб людини гальмує появу і розвиток інших потреб, часто знижує активність або змінює іiі спрямованість. Тривале незадоволення таких потреб веде до виникнення фрустрації - стану, сповненого тривоги, внутрішнього дискомфорту, загальної напруги тощо.

Отже, однією із важливих функцій викладача є стимулювання позитивної мотивації кожного студента в процесі організації різноманітних видів діяльності. Позитивною мотивацією навчальної діяльності студентів може бути створення викладачем таких ситуацій, які б спонукали студентів до пошуку розв'язання проблеми, крок за кроком наближаючи їх до мети.

Актуальними напрямками подальшого розроблення окресленої проблеми $є$ дослідження процесу формування кросс-культурної компетентності майбутніх економістіваграріїв шляхом стимулювання мотивації до навчання.

\section{Література}

1. Бондаренко Н. Б. Мотиви опанування учнями 7-9 класів іноземної мови як засобу самовираження особистості : автореф. дис. на здобуття наук. ступеня канд. пед. наук: 13.00.07 / Н. Б. Бондаренко. - К., 2002. - 18 с. 2. Грабовська Т. Формування позитивної мотивації діяльності особистості / Т. Грабовська, О. Киричук / Рідна школа. - 2002. - № 4. - С. 12-14. 3. Занюк С. С. Психологія мотивації : [навч. посіб.] / С. С. Занюк. - К. : Либідь, 2002. - 304 с. 4. Зеер Э. Ф. Психология профессионального образования: [учеб. пособ.] / Э. Ф. Зеер. - [2-е изд.; перераб.]. - М. : Издательство Московского психолого-социального института; Воронеж: 
Издательство ИПО «МОДЕК»,2003. - 480 с. 5. Ильин Е. П. Мотивация и мотивы : [учеб. пособ.] / Е. П. Ильин. - СПб. : Питер, 2000. - 512 с. 6. Коваленко Е. Э. Методика профессионального обучения: [учеб. для инженеров-педагогов, препод. спец. дисциплин системы проф.-тех. и выс. образов.] / Е. Э. Коваленко. - Х. : Штрих, 2003. - 480 с. 7. Копець Л. В. Психологія особистості : [навч. посіб. для студ. вищ. навч. закл.] / Л. В. Копець. - К. : ВД «КиєвоМогилянська академія», 2008. - 458 с. 8. Красноголова І. Б. Формування мотивів учіння студентів у процесі викладання англійської мови : дис. ... канд. пед. наук / І. Б. Красноголова. - К., 1999. 178 с. 9. Леонтьев А. А. Педагогическое общение / А. А. Леонтьев. - М., 1979. - 48 с. 10. Маркова А. К. Формирование мотивации учения: [книга для учит.] / А. К. Маркова, Т. А. Матис, А. Б. Орлов. - М. : Просвещение, 1990. - 192 с. 11. Маркова А. К. Формирование мотивации учения в школьном возрасте : [пособ. для учит.] / А. К. Маркова. - М. : Просвещение, 1983. - 96 с. 12. Маслоу А. Г. Мотивация и личность / А. Г. Маслоу. - СПб. : Евразия, 2001. 478 с. 13. Никитина Г. В. Формирование творческих умений в процессе профессионального обучения / Г. В. Никитина, В. Н. Романенко - СПб. : Издательство С.-Петербургского гос. унта, 1992. - 268 с. 14. Рубинштейн С. Л. Проблемы общей психологии / С. Л. Рубинштейн. - М. : Просвещение, 1976. - 424 с.

Ю. В. Рибалко, асистент, Національний університет біоресурсів $i$ природокористування України

\section{КОМПЕТЕНТНІСНИЙ ПІДХІД У НАУКОВО- ПЕДАГОГІЧНІЙ ЛІТЕРАТУРІ}

У статті представлено теоретичний аналіз сутності поняття «компетентнісний підхід» у науково-педагогічній літературі.

Ключові слова: компетентнісний підхід, компетентність, компетенuุiя.

В статье представлен теоретический анализ сущности понятия «компетентностный подход» в научно-педагогической литературе.

Ключевые слова: компетентностный подход, компетентность, компетенция.

The paper presents theoretical analysis of the notion "competence approach (access)" in the scientific and educational literature.

Key words: competence approach (access), competence. 